Original Research

\title{
The Use of Iron-Based Sorption Materials and Magnetic Fields for the Removal of Antimony from Water
}

\author{
Ján Ilavský1*, Danka Barloková1, Karol Munka² \\ 'Department of Sanitary and Environmental Engineering, Faculty of Civil Engineering, \\ Slovak University of Technology, Radlinského 11, 81005 Bratislava, Slovak Republic \\ ${ }^{2}$ Water Research Institute, Nábrežie arm. gen. L. Svobodu 5, 81249 Bratislava, Slovak Republic
}

Received: March 3, 2015

Accepted: May 25, 2015

\begin{abstract}
The objective of this work was to verify the sorption properties of granular filter materials (GEH, CFH12, Bayoxide E33) during the process of removing antimony from water, and to monitor the impact of magnetic and electromagnetic fields on the effectiveness of removing antimony from water. Pilot tests showed that the use of iron-based sorption materials could possibly decrease the antimony content in water to the values limited for drinking water $(5 \mu \mathrm{g} / \mathrm{L} \mathrm{Sb})$. The most suitable adsorbent for removing antimony was GEH. At a concentration of antimony in raw water of $81.4 \mu \mathrm{g} / \mathrm{L}$ and a filtration rate of $3.4 \mathrm{~m} / \mathrm{h}$, a value of bed volume 2,030 and adsorption capacity of $144.7 \mu \mathrm{g} / \mathrm{g}$ was determined; at the filtration rate of $5.6 \mathrm{~m} / \mathrm{h}$, the bed volume was 1,342 , and the adsorption capacity was $96.8 \mu \mathrm{g} / \mathrm{g}$ achieved at breakthrough concentration $5 \mu \mathrm{g}$ $\mathrm{Sb} / \mathrm{L}$. The results presented from testing the effects of a permanent magnet and electromagnet in removing antimony are not well known, as only a few experiments have been conducted.
\end{abstract}

Keywords: drinking water, removal of antimony, iron-based sorption materials, permanent magnet, electromagnet

\section{Introduction}

Elemental antimony $(\mathrm{Sb})$ is a silvery white, brittle solid that, along with arsenic and bismuth, belongs to group VA of the periodic table. It is classified as both a metal and a metalloid.

Antimony is present in the Earth's crust at a concentration of about $0.2-0.5 \mathrm{mg} / \mathrm{kg}$. It is seldom found in the environment as a pure element, but it is often found as trivalent and pentavalent sulphides and chlorides. Antimony may enter the aquatic environment by way of natural weathering of rocks, runoff from soils, effluents from mining and manufacturing operations, and industrial and municipal leachate discharges.

*e-mail: jan.ilavsky@stuba.sk
Antimony is present in water as $\mathrm{Sb}^{3-}, \mathrm{Sb}^{0}, \mathrm{Sb}^{3+}$, and $\mathrm{Sb}^{5+}$ $\left(\mathrm{Sb}^{3+}\right.$ is 10 times more toxic than $\left.\mathrm{Sb}^{5+}\right)$, depending on water $\mathrm{pH}$, the oxidation-reduction potential $\left(\mathrm{Sb}^{3+} / \mathrm{Sb}^{5+}\right.$ ratio), and oxygen concentration. It is found mainly in the form of antimonate as oxyanions $\left(\mathrm{H}_{2} \mathrm{SbO}_{4}\right)^{-}$and $\left(\mathrm{HSbO}_{4}\right)^{2-}$, or it can be present in the form of antimonite $\left(\mathrm{H}_{3} \mathrm{SbO}_{4}\right)[1,2]$.

Antimony is a toxic heavy metal with effects similar to those of arsenic and lead. Intoxication by antimony is not as severe as that from arsenic, since the antimony compounds are absorbed more slowly. The findings on the health aspects of certain heavy metals in drinking water are included in several publications [3-5]. The World Health Organization and institutions dealing with monitoring carcinogens have not yet classified antimony as a carcinogen. 
In Slovakia, an acceptable concentration of heavy metals in drinking water is defined under the Government Regulation No. 496/2010 on Drinking Water. The limit concentration for antimony is $5 \mu \mathrm{g} / \mathrm{L}$, which is in accordance with WHO recommendations [6, 7] and the EU Directive (98/83/EC 1998).

The Dúbrava group water supply system in Slovakia was built in connection with the construction of the Liptovská Mara Water Reservoir. The water resource included three springs (Brdáre, Močidlo, and Škripeň). Škripeň is currently the only spring used for a drinking water supply since it contains no antimony. Two other springs are contaminated with antimony.

A deposit of antimony ore is considered to be the main cause of the increased antimony concentrations in the spring of Močidlo and Brdáre. Furthermore, a high concentration of antimony in water from mining activities as well as from rain falling on antimony-rich waste rock piles and a sludge-settling pond has led to higher concentrations of antimony in the relevant water resources.

Water quality monitoring data is provided by the Water Company of the Region of Liptov. The highest contamination from antimony was observed in water from Brdáre Spring, where the concentrations ranged from 80.3 to 91.3 $\mu \mathrm{g} / \mathrm{L}$. The concentration of antimony in water from Močidlo Spring was 70.6-82.0 $\mu \mathrm{g} / \mathrm{L}$. Obviously, the best water quality was monitored in Škripen Spring, where the concentration of $\mathrm{Sb}$ was lower than $1 \mu \mathrm{g} / \mathrm{L}$. No other heavy metals were present in the Dúbrava water resource.

During the model tests the quality of the raw water (Brdáre Spring) was evaluated, and concentrations of several other parameters were determined: $\mathrm{pH} 7.6-7.9$, alkalinity 1.7-2.2 $\mathrm{mmol} / \mathrm{L}$, conductivity $22.5-28.7 \mathrm{mS} / \mathrm{m}, \mathrm{Ca}^{2+} 28-32$ $\mathrm{mg} / \mathrm{L}, \mathrm{Mg}^{2+}$ 9.7-15.8 mg/L, $\mathrm{Cl}^{-}[\mathrm{mg} / \mathrm{L}]$ 7.2-10.6, $\mathrm{SO}_{4}^{2-}$ $[\mathrm{mg} / \mathrm{L}] 10.2-18.6, \mathrm{~F}^{-}[\mathrm{mg} / \mathrm{L}]$ 0.01-0.12, and $\mathrm{PO}_{4}^{3-}[\mathrm{mg} / \mathrm{L}]$ 0.01-0.08. Several technological methods can remove heavy metal in the water treatment process: precipitation, ion exchange, membrane processes, adsorption, electrochemical processes, and biological methods [8-10].

Adsorption using an appropriate sorption material is preferred for water treatment when considering small water resources. Sorption is a simple (regarding its operation) and effective method of heavy metal removal. The most frequently tested sorbents are as follows: iron oxides and oxyhydroxides, activated alumina, sand covered by iron hydroxide, activated carbon, magnesium hydroxide, media containing $\mathrm{TiO}_{2}$ or $\mathrm{MnO}_{2}$ layers on their surface, etc. $[11,12]$.

A number of experiments and model studies of the adsorption of arsenic and other heavy metals are described in various publications [13-31]. These studies describe sorption processes at different $\mathrm{pH}$ values, initial heavy metal ion concentrations in water, solid/liquid ratio, particle size of a sorption material, filtration rate, temperature and composition of water to be treated (concentration of iron, manganese, phosphorus, silicon, fluorides, sulphates, organic matter, etc.).

Works dealing with antimony removal from water by adsorption on iron-based materials is less than the works concerned with the removal of arsenic. The authors of work [32] monitored the efficiency of iron-based materials (GEH, CFH18) used not only in the removal of arsenic but antimony from water, too. Mariussen et al., at work [33] monitored removal of antimony in runoff water from a small-arms shooting range with a combination of charcoal and iron hydroxide. Results of removal of antimony from water with iron-based materials are presented in papers of Mitsonobu et al. [34] and Sazakli et al. [35]. Sazakli et al. studied the efficiency of a granular ferric oxide adsorbent (Bayoxide E33) to remove arsenic and antimony from drinking water. Three different water matrices - deionized, raw water treated with a reverse osmosis domestic device, and raw water - were spiked with arsenic and/or antimony to a concentration of $100 \mu \mathrm{g} \cdot \mathrm{L}^{-1}$. Both elements were successfully adsorbed onto the medium Bayoxide E33. The loadings until the guideline value was exceeded in the effluent were found to be 0.35 $1.63 \mathrm{mg} \cdot \mathrm{g}^{-1}$ for arsenic and $0.12-2.11 \mathrm{mg} \cdot \mathrm{g}^{-1}$ for antimony, depending on the water matrix. Adsorption of one element was not substantially affected by the presence of the other. Granular ferric oxide could be employed for the simultaneous removal of arsenic and antimony from drinking water.

The objective of this work was to verify the sorption properties of granular iron-based filter materials $(\mathrm{GEH}$, CFH12, CFH18, Bayoxide E33) in the Dúbrava water resource during the process of antimony removal from water and to monitor the impact of magnetic and electromagnetic fields on the effectiveness of antimony removal from water. The effect of a magnetic field is not evaluated in relation to water quality (elimination of inlay, reducing water hardness), but its effect in increasing the adsorption properties of the surface adsorbent layer (the interaction of Fe materials and the magnetic field) is analyzed.

\section{Experimental Procedures}

The pilot tests for removing antimony were carried out at the Dúbrava chlorination plant (Fig. 1). At present, only water from the Škripeň well is conveyed into the storage tank of the chlorination plant. After its disinfection, the water is gravitationally distributed to the point of consumption. For the purpose of these simulation tests, there was a need to convey the water from Brdáre well to the chlorination plant through a separate pipe in order to avoid mixing it with the water from the Škripeň well.

\section{Adsorbents}

Bayoxide E33 is a granular iron oxide-based medium. It was developed by Severn Trent in cooperation with Bayer AG for the removal of arsenic and other contaminants from water. The advantage of this material is its ability to remove $\mathrm{As}^{3+}$ and $\mathrm{As}^{5+}$ together with iron and manganese [35-37].

CFH12 is a granular sorption materials based on iron oxyhydroxides. They were developed by Kemira Finland as effective products for the removal of arsenic and other contaminants from water by adsorption [38, 39]. 
Table 1. Physical and chemical properties of select sorption materials.

\begin{tabular}{|l|c|c|c|}
\hline \multicolumn{1}{|c|}{ Parameter } & Bayoxide E33 & $\mathrm{CFH} 12$ & $\mathrm{GEH}$ \\
\hline Matrix/Active agent & $\mathrm{Fe}_{2} \mathrm{O}_{3}>70 \%$ and $90.1 \% \alpha-\mathrm{FeOOH}$ & $\mathrm{FeOOH} \mathrm{Fe}{ }^{3+}>40 \%$ & $\mathrm{Fe}(\mathrm{OH})_{3}$ and $52-57 \% \beta-\mathrm{FeOOH}$ \\
\hline Physical form & dry granular & dry granular & moist granular \\
\hline Color & amber & brown-red & dark brown \\
\hline Bulk density $\left[\mathrm{g}^{\mathrm{c}} \mathrm{cm}^{-3}\right]$ & 0.45 & $1.12-1.2$ & $1.22-1.29$ \\
\hline Specific surface area $\left[\mathrm{m}^{2} \cdot \mathrm{g}^{-1}\right]$ & $120-200$ & 120 & $250-300$ \\
\hline Grain size $[\mathrm{mm}]$ & $0.5-2.0$ & $0.5-2.0$ & $0.32-2.0$ \\
\hline Grain porosity $[\%]$ & 85 & $75-80$ & $72-80$ \\
\hline Operating $\mathrm{pH}$ range & $6.0-8.0$ & $6.5-7.5$ & $5.5-9.0$ \\
\hline
\end{tabular}

Table 2. Chemical composition of select sorption materials.

\begin{tabular}{|l|c|c|c|c|c|c|c|c|c|}
\hline \multirow{2}{*}{ Material } & \multicolumn{8}{|c|}{ Compound in mass [\%] } \\
\cline { 2 - 11 } & $\mathrm{MgO}$ & $\mathrm{Al}_{2} \mathrm{O}_{3}$ & $\mathrm{SiO}_{2}$ & $\mathrm{P}_{2} \mathrm{O}_{3}$ & $\mathrm{SO}_{\mathrm{x}}$ & $\mathrm{K}_{2} \mathrm{O}$ & $\mathrm{CaO}$ & $\mathrm{TiO}_{2}$ & $\mathrm{Fe}_{2} \mathrm{O}_{3}$ \\
\hline $\mathrm{E} 33$ & 0.97 & 6.59 & 12.75 & 0.34 & 0.31 & 0.37 & 2.01 & 0.91 & 75.28 \\
\hline $\mathrm{CFH12}$ & 3.75 & 0.45 & 1.18 & - & 8.49 & 0.27 & 2.72 & 0.50 & 82.65 \\
\hline GEH & - & 1.74 & 3.05 & 0.21 & 0.54 & 0.08 & 0.18 & - & 91.92 \\
\hline
\end{tabular}

The GEH was obtained from the supplier (GEH Wasserchemie, Germany). GEH is a sorption material developed by the Department of Water Quality Monitoring of the University of Berlin for the purpose of arsenic removal from water. GFH consists of ferric hydroxide and oxyhydroxide with dry solid content $57 \%( \pm 10 \%)$ by mass, and $43-48 \%$ by mass moisture content. Iron content is 610 $\mathrm{g} / \mathrm{kg}( \pm 10 \%)$ relative to dry solids [40-45].

Tables 1 and 2 include the basic physical-chemical properties and chemical composition of the select sorption materials used in the test.

The chemical composition of the dry sorption materials (Table 2) was analyzed using X-Ray microanalysis, SEM, and X-ray phase analysis.
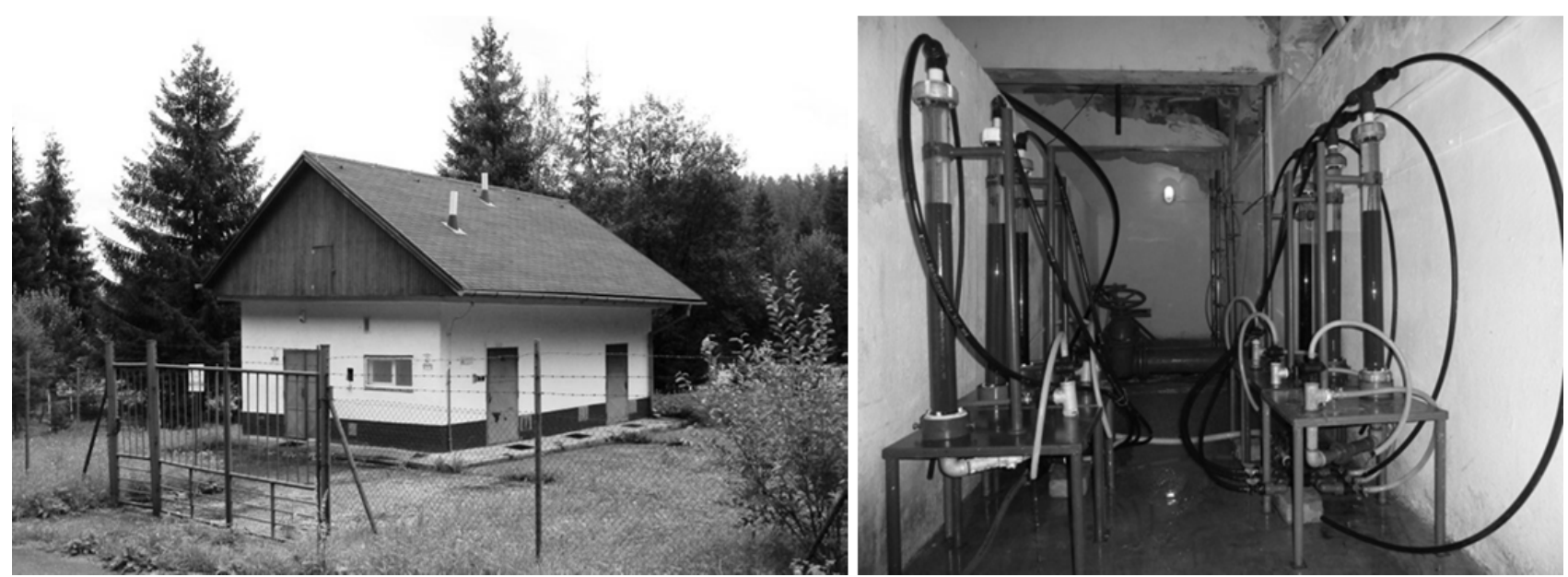

The shape and the external surface of sorption materials GEH, CFH12, and Bayoxide E33 were taken by scanning electron microscope. Figs. 2 and 3 illustrate differences in character of surfaces.

\section{Model Filtration System}

The effectiveness of antimony removal was verified using adsorption columns containing the select sorption material. The adsorption column was made of glass with a diameter of $5.0 \mathrm{~cm}$. The height of the media ranged from 50 to $53 \mathrm{~cm}$, and the total height of the glass column was $80 \mathrm{~cm}$.

Raw water (Brdáre Spring) passed through the filtration system (Fig. 1), and the concentration of antimony was

Fig. 1. Dúbrava chlorination plant and model filtration columns. 

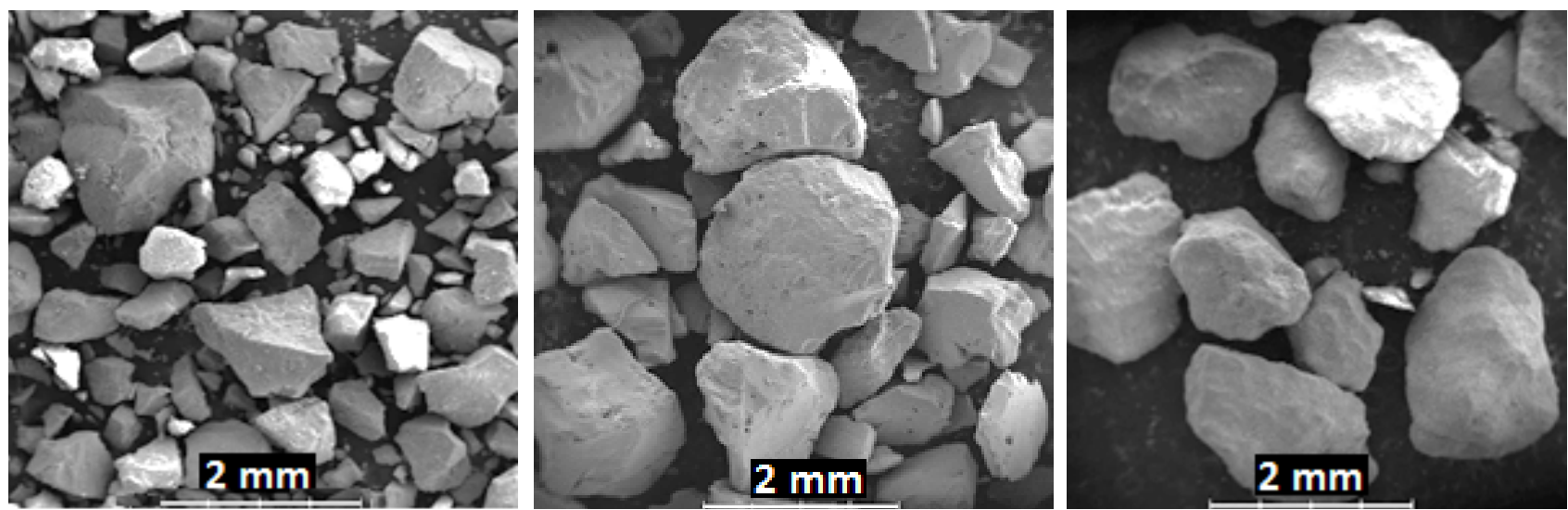

Fig. 2. Microstructures of GEH, Bayoxide E33, and CFH12 (40× magnification).
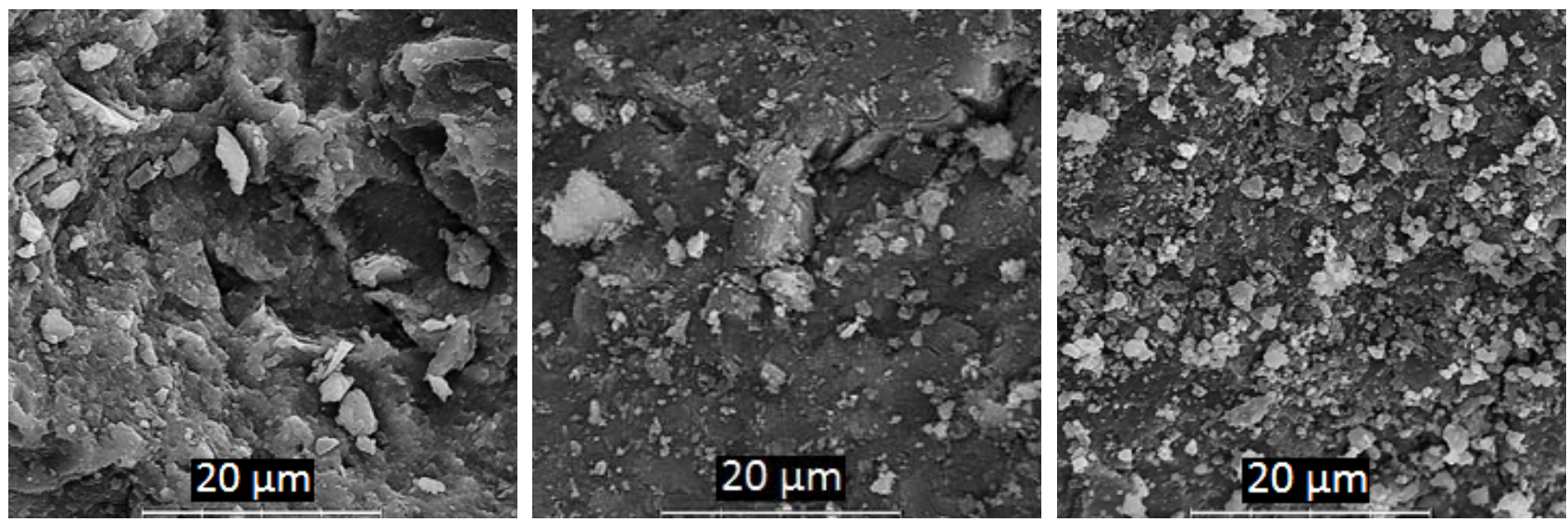

Fig. 3. Microstructures of GEH, Bayoxide E33, and CFH12 (5,000× magnification).

monitored in raw and treated water at the outlets of the filtration columns. Simultaneously, the flow rates were measured at the outlet of each column. A system of several valves was used for feeding the water for the filtration system (from top to bottom) and for the filter backwash (from bottom to top), as well as for regulating the filtration rates.

\section{Magnetic Field}

The objective of the model tests was to verify the effect of a permanent magnet and electromagnet on the effectiveness of antimony sorption by iron-based sorption materials (the interaction of the Fe materials and the magnetic field increase the adsorption properties of the surface adsorbent layer). The tests were carried out along with standard model tests of antimony removal in order to perform them under the same operating conditions (Fig. 4).

A magnetic hard water conditioner (magnetizer) and EZV20D equipment were used in the model tests (Fig. 5). The magnetizer is designed for the magnetic treatment of liquids. A magnetizer can be placed on any type of piping (steel, stainless steel, galvanized, plastic, rubber, etc.). It is protected against the weather. A magnetizer is based on permanent magnetism with a very high magnetic flux density $(1.12 \mathrm{~T})$. There is no conventional ferrite composition; the construction material belongs among the so-called ceramic magnets. The particular technical specification is a single focal monopolistic structure with an affirmative performance that uses magnetic poles set against each other.

The basic principle of EZV equipment is physical water treatment with an electronically controlled electromagnetic field. The EZV type 20D contains a pulse generator, which is controlled by a microcomputer and a coil with 11 turns on the pipes that transport the water. The EZV equipment sends precisely programmed, highly non-periodic impulses

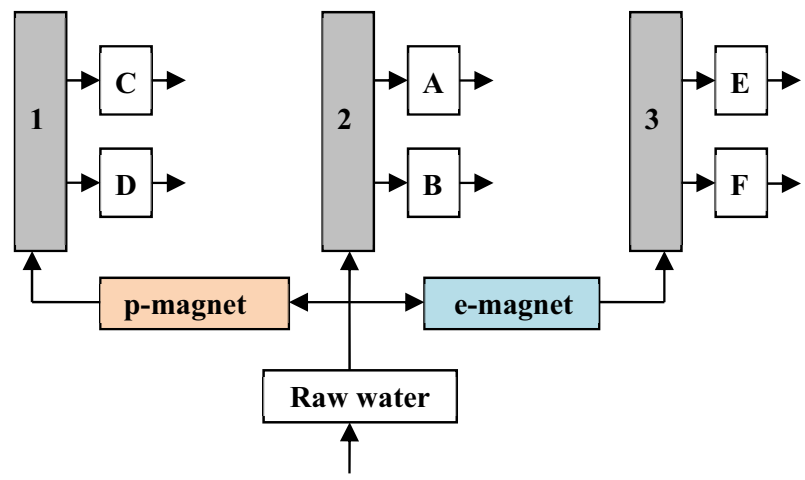

Fig. 4. Technological scheme of the model equipment for verifying the effect of the permanent magnet and electromagnet on removing antimony from water. 

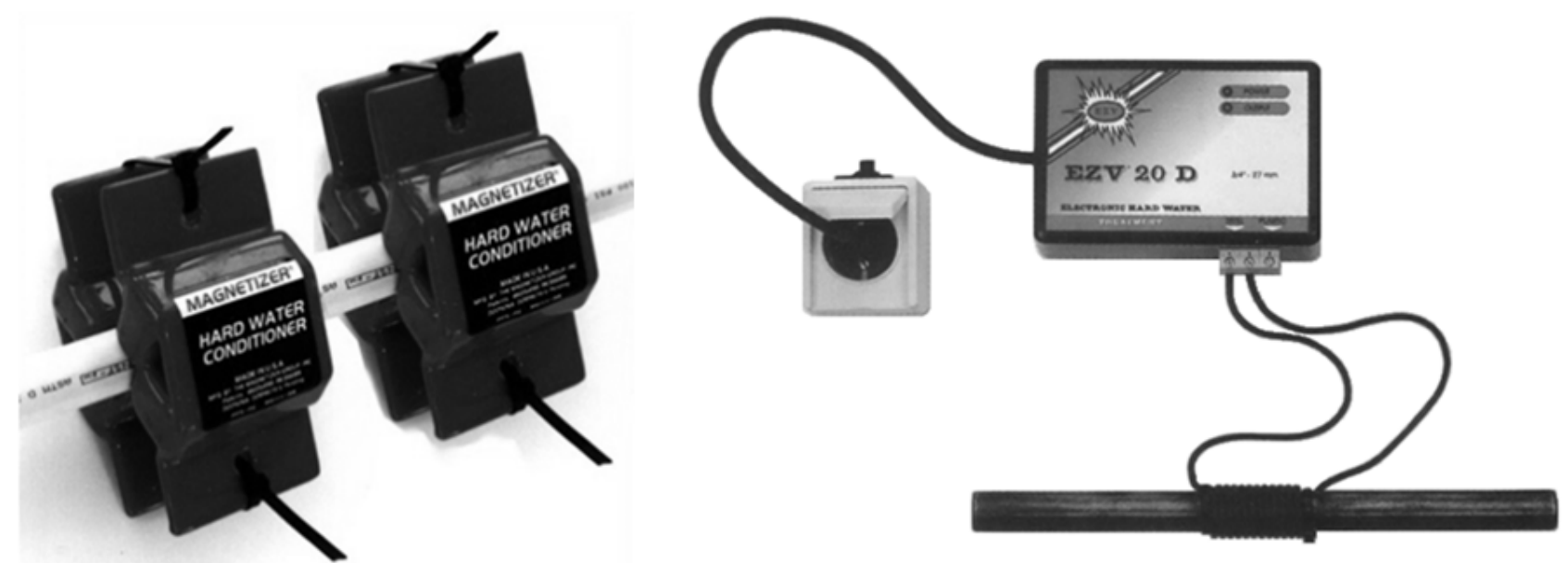

Fig. 5. Physical treatment of water by permanent magnet (magnetizer) and electromagnetic field (EZV 20D).

to the coil that disrupt the micro-particles in the water The EZV power supply is $230 \mathrm{~V}$, while power consumption is $2 \mathrm{~W}$. The EZV has an output to the metal and plastic. The coil that generates the magnetic field must be wound on a straight section of the pipe (at least three times the pipe's diameter); the coil can be mounted in a horizontal or vertical position.

\section{Analytical Method}

Antimony samples after passing through columns were collected in plastic bottles and immediately acidified with highly pure nitric acid (Merck). All bottles were submerged in $10 \%$ nitric acid solution over three days and triple rinsed with de-ionized water. Agilent 7500CE ICP-MS (ORS technology) was used to determine antimony concentration in solution. The detection limit for Sb by ICP-MS was $1 \mu \mathrm{g} / \mathrm{L}$.

\section{Results and Discussion}

Model Test without Magnetic Field

The first stage of the model tests was aimed at monitoring the effectiveness of the iron-based sorption materials GEH, CFH12 and Bayoxide E33 for the removal of antimony from water. The concentrations of antimony in the raw water ranged from 55 to $62 \mu \mathrm{g} / \mathrm{L}$ (an average of $58.3 \mu \mathrm{g} / \mathrm{L}$ ); the media height was $50 \mathrm{~cm}$, the volume of adsorption column was $982 \mathrm{~cm}^{3}$, the medium mass were 1,227.5 $\mathrm{g}$ for GEH, $441.9 \mathrm{~g}$ for Bayoxide E33, and 1,102.8 for $\mathrm{CFH} 12$, the filtration rates were $4.7-5.3 \mathrm{~m} / \mathrm{h}$ for the $\mathrm{GEH}, 4.3-4.9 \mathrm{~m} / \mathrm{h}$ for the Bayoxide E33, and 4.3-5.1 m/h for the CFH12, and the empty bed contact times (EBCT) were $6.0,6.4$, and $6.3 \mathrm{~min}$, respectively.

Fig. 6 shows the breakthrough curves of antimony as a function of water volumes treated in terms of bed volumes,
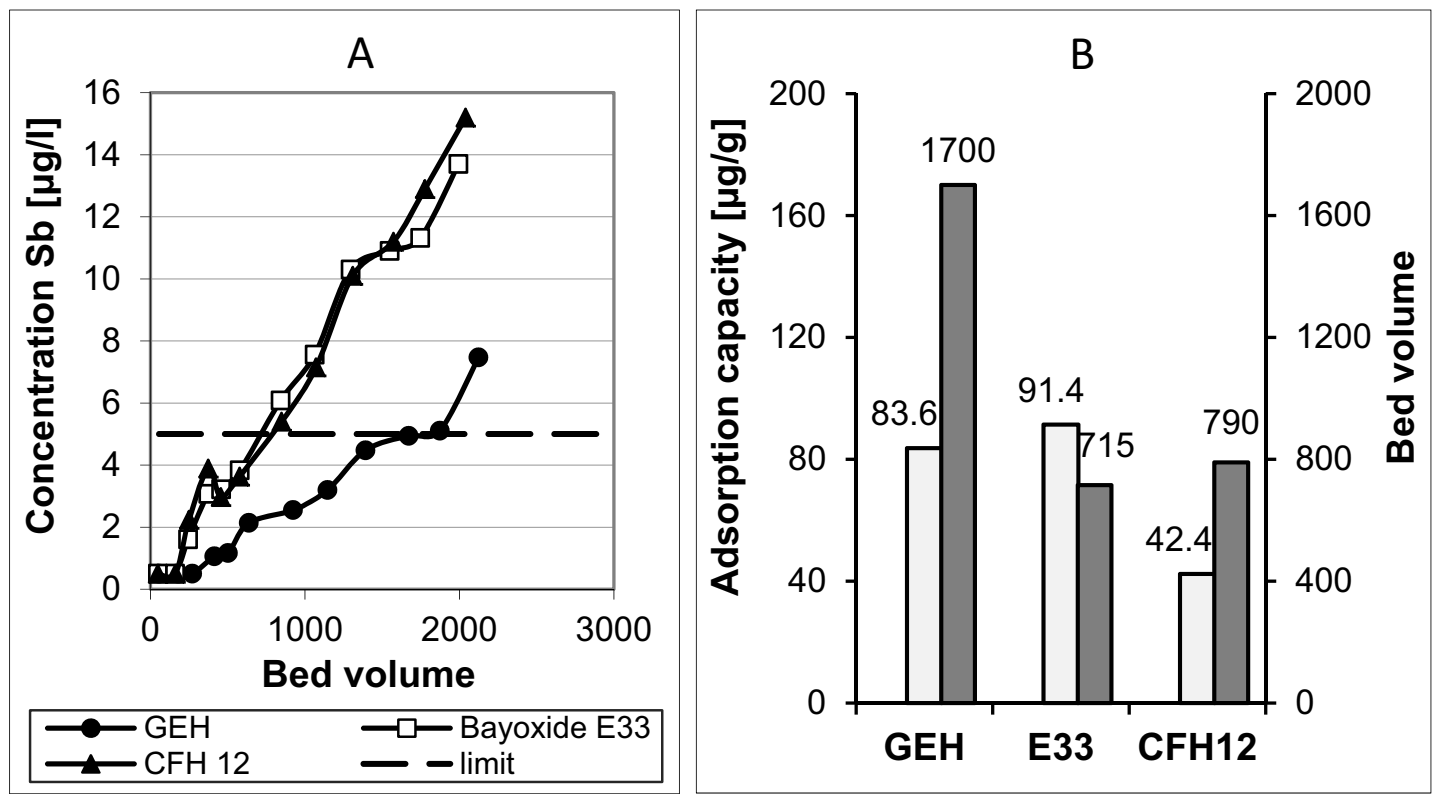

Fig. 6. Breakthrough curves of antimony (A) and the bed volumes and adsorption capacity achieved (B) at breakthrough concentration of $5 \mu \mathrm{g} \mathrm{Sb} / \mathrm{L}$ (raw water concentration $58.3 \mu \mathrm{g} \mathrm{Sb} / \mathrm{L}$, media height $50 \mathrm{~cm}$ ). 
and the values of the bed volume or the adsorption capacity for each sorption material when reaching the limit concentration of antimony $(5 \mu \mathrm{g} / \mathrm{L})$.

Considering the minimum differences in the filtration rates and based on the results presented in Fig. 6, it can be concluded that GEH is the most suitable material for antimony removal compared to the other sorbents used in the test. The following bed volumes were measured for the antimony concentration $(5 \mu \mathrm{g} / \mathrm{L})$ at the outlet of the adsorbent media: bed volume 1,700 for GEH, 790 for CFH12, and 715 for Bayoxide E33. The adsorption capacities were as follows: $\mathrm{GEH}=83.6 \mu \mathrm{g} / \mathrm{g}$, Bayoxide E33=91.4 $\mu \mathrm{g} / \mathrm{g}$ (a higher adsorption capacity of Bayoxide E33 is caused by the 2.5 times lower bulk density of this material), and $\mathrm{CFH} 12=42.4 \mu \mathrm{g} / \mathrm{g}$.

The values of adsorption capacity for the GEH and Bayoxide E33 media are in contrast to the development of the antimony concentration at the outlets of the GEH and Bayoxide E33 media, depending on the bed volume. A significantly higher effectiveness of the antimony removal from the water using GEH can be seen in Fig. 6 . Therefore, if there are used and compared sorbents with different bulk densities (Table 2), the effectiveness of sorption materials would be suitable for expression using of the bed volume.

Like at work, EPA/600/R-09/016 [32] as well in our experiments for the removal of antimony GEH was the most effective for a given water quality $(\mathrm{pH}$, concentration of $\mathrm{Sb}$, etc.) and conditions during experiments (filtration rate, contact time).

\section{Model Test with Permanent Magnet}

The objective of the second stage of the model tests was to evaluate the effect of a permanent magnet ( $p$-magnet) on antimony removal from water using the sorption materials
GEH, Bayoxide E33, and CFH12 (the media height was 52 $\mathrm{cm}$, the volume of adsorption column $1,021 \mathrm{~cm}^{3}$; the medium masses were 1,276.6 $\mathrm{g}$ for $\mathrm{GEH}, 459.6 \mathrm{~g}$ for Bayoxide $\mathrm{E} 33$, and 1,146.9 $\mathrm{g}$ for CFH12) in six glass columns. Raw water (the Brdáre well) passed through the media contained in the first three columns. The other three columns were fed by water that had previously flowed through a permanent magnet.

The antimony concentrations in raw water ranged from 69 to $77 \mu \mathrm{g} / \mathrm{L}$ (average of $72.6 \mu \mathrm{g} / \mathrm{L}$ ) during the tests of the effect of the permanent magnet, and filtration rates were 5.0-5.8 $\mathrm{m} / \mathrm{h}$, and the EBCTs were 5.6-5.8 $\mathrm{min}$ for each filtration column.

Fig. 7 shows the breakthrough curves of antimony as a function of bed volumes, and the values of the bed volume or the adsorption capacity for each sorption material when reaching the limit concentration of antimony $(5 \mu \mathrm{g} / \mathrm{L})$.

As can be seen in Fig. 7, no effect of the permanent magnet on the increase in the effectiveness of CFH12 and Bayoxide E33 was observed. On the contrary, the permanent magnet had a positive effect on the increase in the effectiveness of GEH in antimony removal.

In removing antimony using $\mathrm{GEH}$, the concentration of antimony at the media outlet reached the limit value $(5 \mu \mathrm{g} / \mathrm{L})$ at bed volume 610 , but this value increased to 1,550 with the effect of the permanent magnet. This means that the value of the bed volume increased 2.5 times. The value of the bed volume decreased from 430 to 205 for CFH12 and from 110 to 64 for Bayoxide E33. Moreover, the permanent magnet had an effect on the increase in adsorption capacity from $34.3 \mu \mathrm{g} / \mathrm{g}$ to $87.9 \mu \mathrm{g} / \mathrm{g}$ (Fig. 7).

Figs. 6 and 7 show a significant difference in the measured values of the bed volume and adsorption capacity for Bayoxide E33 media, which was caused by the use of new material (pellets) during the second stage of the model tests.
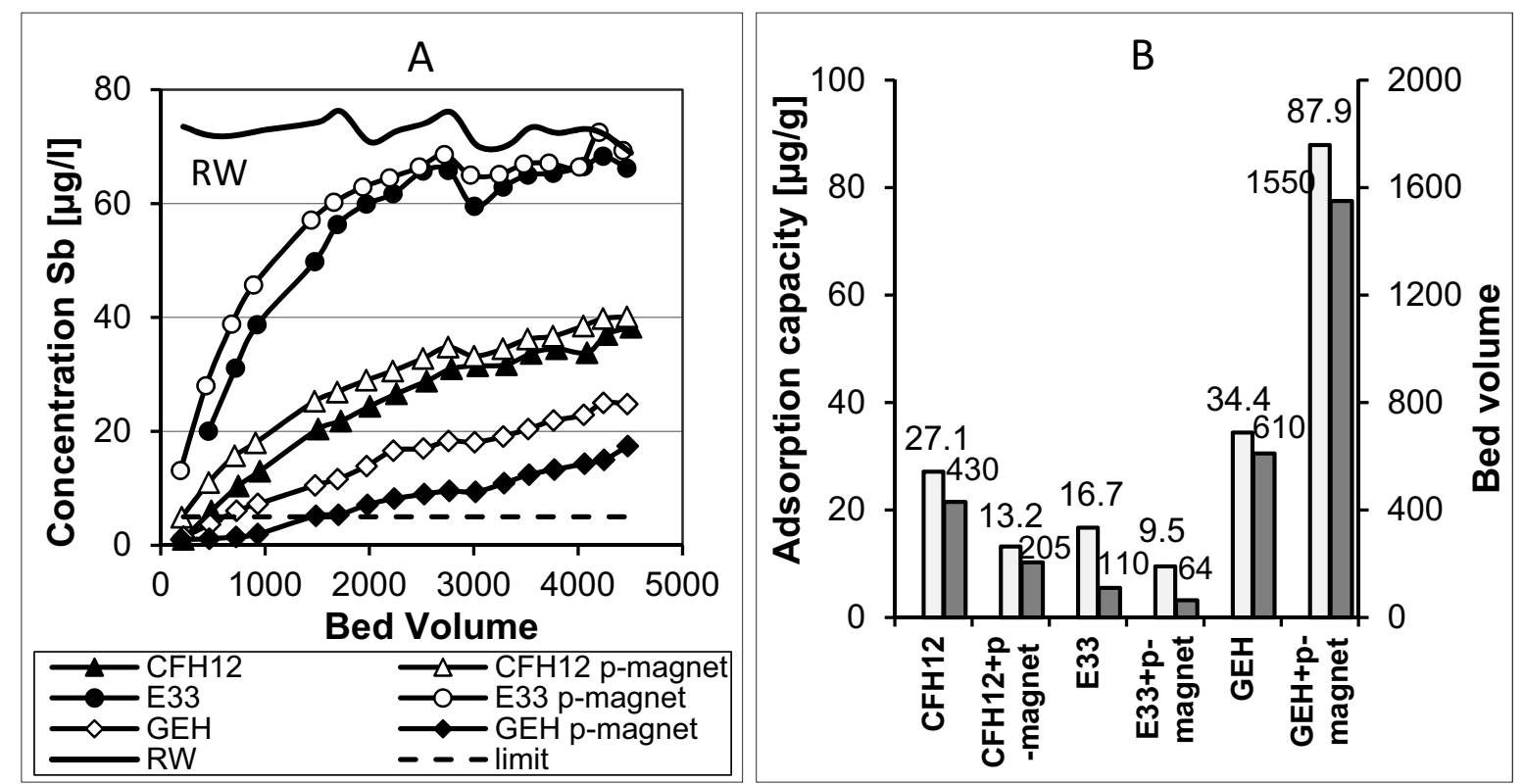

Fig. 7. Breakthrough curves of antimony (A) and bed volumes and adsorption capacity achieved (B) at breakthrough concentration of $5 \mu \mathrm{g} \mathrm{Sb} / \mathrm{L}$ (raw water concentration $72.6 \mu \mathrm{g} \mathrm{Sb} / \mathrm{L}$, media height $52 \mathrm{~cm}$, filtration rate $5.0-5.8 \mathrm{~m} / \mathrm{h}$ ). 


\section{Model Test with GEH, Permanent Magnet, Electromagnet, and Different Filtration Rate}

The third stage of the experiments was aimed at verifying the effect of the permanent magnet and electromagnet on the increase in the effectiveness of GEH for removing antimony from water (GEH was the most efficient sorbent in antimony removal) in relation to the filtration rate. The filtration systems were operated in the following way: only raw water flowed through the media in two columns; the other two columns were supplied with water that had previously flowed through the permanent magnet; the remaining two columns were fed by water after its exposure to the effect of the electromagnet. The tests were carried out under the same flow conditions for tree columns at a filtration rate of 5.4-5.6 m/h and for tree columns at a filtration rate of 3.1-3.4 m/h. The height of the filtration media GEH in the columns was $51-52 \mathrm{~cm}$, the volume of adsorption column was 1,001-1,021 $\mathrm{cm}^{3}$, and the medium mass was 1,121.5-1,143.5 g). The concentrations of $\mathrm{Sb}$ in the raw water were significantly higher compared to the previous experiments (in a range from 78 to $88 \mu \mathrm{g} / \mathrm{L}$; average value $81.4 \mu \mathrm{g} / \mathrm{L}$ ), and this led to the increased concentration loading of the media.

Fig. 8 shows the breakthrough curves of antimony as a function of bed volumes (at a filtration rate in a range of 3.1-3.4 $\mathrm{m} / \mathrm{h}$ ), and the values of the bed volume or the adsorption capacity for each sorption material when reaching the limit concentration of antimony.

The results demonstrate that at a given filtration rate, the limit concentration of antimony $(5 \mu \mathrm{g} / \mathrm{L})$ was exceeded at bed volume 2,030 for GEH with no effect from the magnet, while the limit concentration under the effect of the permanent magnet and electromagnet was exceeded at bed volumes 1,883 and 1,885 , respectively. The adsorption capacity in relation to the limit concentration at the media outlet was $144.7 \mu \mathrm{g} / \mathrm{g}$ for GEH with no effect from the magnet, while under the effect of the permanent magnet and electromagnet it was $135.8 \mu \mathrm{g} / \mathrm{g}$ and $134.3 \mu \mathrm{g} / \mathrm{g}$, respectively.

Fig. 9 shows the breakthrough curves of antimony as a function of bed volumes (at a filtration rate in a range of 5.4-5.6 $\mathrm{m} / \mathrm{h}$ ), and the values of the bed volume or the adsorption capacity for each sorption material when reaching the limit concentration of antimony.

The limit concentration $(5 \mu \mathrm{g} / \mathrm{L})$ was observed at bed volume 1,342 for GEH with no effect from the magnet. The limit concentration under the effect of the permanent magnet and electromagnet was reached at bed volume 789 and 839 , respectively. The adsorption capacities, which correspond to such conditions, were lower in comparison to the filtration rate in a range of 3.1-3.4 m/h due to a higher hydraulic loading of sorption media: $96.9 \mu \mathrm{g} / \mathrm{g}$ for GEH with no effect from the magnet, $60.6 \mu \mathrm{g} / \mathrm{g}$ under the effect of the permanent magnet, and $58.6 \mu \mathrm{g} / \mathrm{g}$ under the effect of the electromagnet (Fig. 9).

As can be seen from Figs. 8 and 9, the effect of the permanent magnet and electromagnet on the increase in the effectiveness of the antimony removal from water by using the GEH sorption material was not observed in these tests.

\section{Conclusion}

The technological tests performed on the groundwater from the spring in Dúbrava showed that the use of sorption materials can possibly decrease the content of antimony in water to the values limited by Government Regulation No. 496/2010 on Drinking Water.

Based on the pilot tests, the most suitable sorption material for removing antimony from water is GEH. Achieved values of adsorption capacity and bed volume for GEH material during all experiments are shown in Table 3.
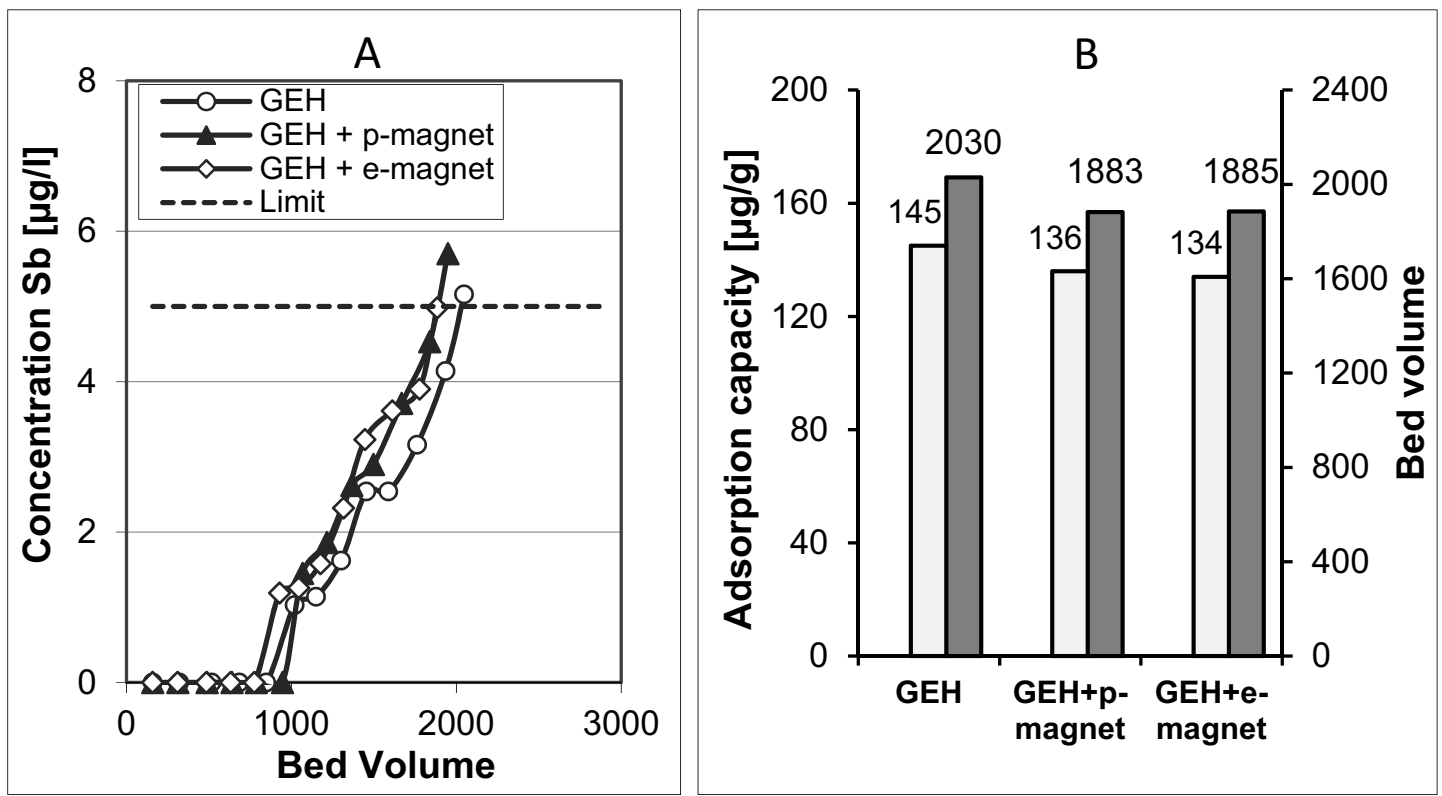

Fig. 8. Breakthrough curves of antimony (A) and bed volumes and adsorption capacity achieved (B) at breakthrough concentration of $5 \mu \mathrm{g} \mathrm{Sb} / \mathrm{L}$ (raw water concentration $81.4 \mu \mathrm{g} \mathrm{Sb} / \mathrm{L}$, filtration rate 3.1-3.4 m/h, EBCT 9.1-9.8 $\mathrm{min}$ ). 
Table 3. The values of bed volume and adsorption capacity of GEH material for different concentrations of antimony in raw water, filtration rates, height media, and EBCT.

\begin{tabular}{|l|c|c|c|c|c|c|}
\hline \multicolumn{1}{|c|}{ Material } & $\begin{array}{c}\text { Concentration of } \\
\mathrm{Sb}[\mu \mathrm{g} / \mathrm{L}] \text { in RW }\end{array}$ & $\begin{array}{c}\text { Average Filtration } \\
\text { rate }[\mathrm{m} / \mathrm{h}]\end{array}$ & $\begin{array}{c}\text { Height media } \\
{[\mathrm{mm}]}\end{array}$ & $\begin{array}{c}\text { EBCT } \\
{[\mathrm{min}]}\end{array}$ & $\begin{array}{c}\text { Bed volume } \\
\left(\mathrm{V} / \mathrm{V}_{0}\right)\end{array}$ & $\begin{array}{c}\text { Adsorption } \\
\text { capacity }[\mu \mathrm{g} / \mathrm{g}]\end{array}$ \\
\hline GEH & 58.3 & 5.0 & 50 & 6.0 & 1,700 & 83.6 \\
\hline GEH & 72.6 & 5.5 & 52 & 5.7 & 610 & 34.4 \\
\hline GEH + p-magnet & 72.6 & 5.5 & 52 & 5.7 & 1,550 & 87.9 \\
\hline GEH & 81.4 & 3.4 & 51 & 9.1 & 2,030 & 145 \\
\hline GEH & 81.4 & 5.6 & 51 & 5.4 & 1,342 & 96.9 \\
\hline GEH + p-magnet & 81.4 & 3.3 & 52 & 9.5 & 1,883 & 136 \\
\hline GEH + p-magnet & 81.4 & 5.4 & 52 & 5.7 & 839 & 60.6 \\
\hline GEH + e-magnet & 81.4 & 3.1 & 51 & 9.8 & 1,885 & 134 \\
\hline GEH + e-magnet & 81.4 & 5.4 & 52 & 5.7 & 789 & 58.6 \\
\hline
\end{tabular}

Filtration rate, height of the filter media (i.e. EBCT), and antimony concentrations influence the value of adsorption capacity and bed volume in raw water. Therefore, pilot tests to verify these values directly on a water source are needed.

The effectiveness of sorption materials is expressed in their adsorption capacity, but in the cases of use (comparison) of sorbents with different bulk densities is not correct, and the effectiveness of sorption would be suitable to be expressed using bed volume.

To improve the economics of water treatment, it is necessary to continue with experimental work to determine if this method could be suitable for removing antimony from water. In the case of the increased water demand for the Liptovský Mikuláš Region, it is possible to treat the water from the Dúbrava water supply reservoir using at least two enclosed filter systems containing a GEH medium (serial filters) with a filtration rate no higher than $4.5 \mathrm{~m} \cdot \mathrm{h}^{-1}$.

The results prove that $\mathrm{CFH} 12$ and Bayoxide E33 materials can also be used to decrease the concentration of $\mathrm{Sb}$ in drinking water below the limit value of $5 \mu \mathrm{g} / \mathrm{L}$. The adsorption capacities and bed volumes are lower for these sorption materials in comparison to GEH.

The current results from testing the effect of a permanent magnet and electromagnet for antimony removal using select adsorption materials are not well known, as only a few experiments have been conducted. No stronger positive effect of a permanent magnet on the effectiveness of antimony removal using GEH than in a situation where the bed volume for the limit concentration of $\mathrm{Sb}$ at the outlet of the
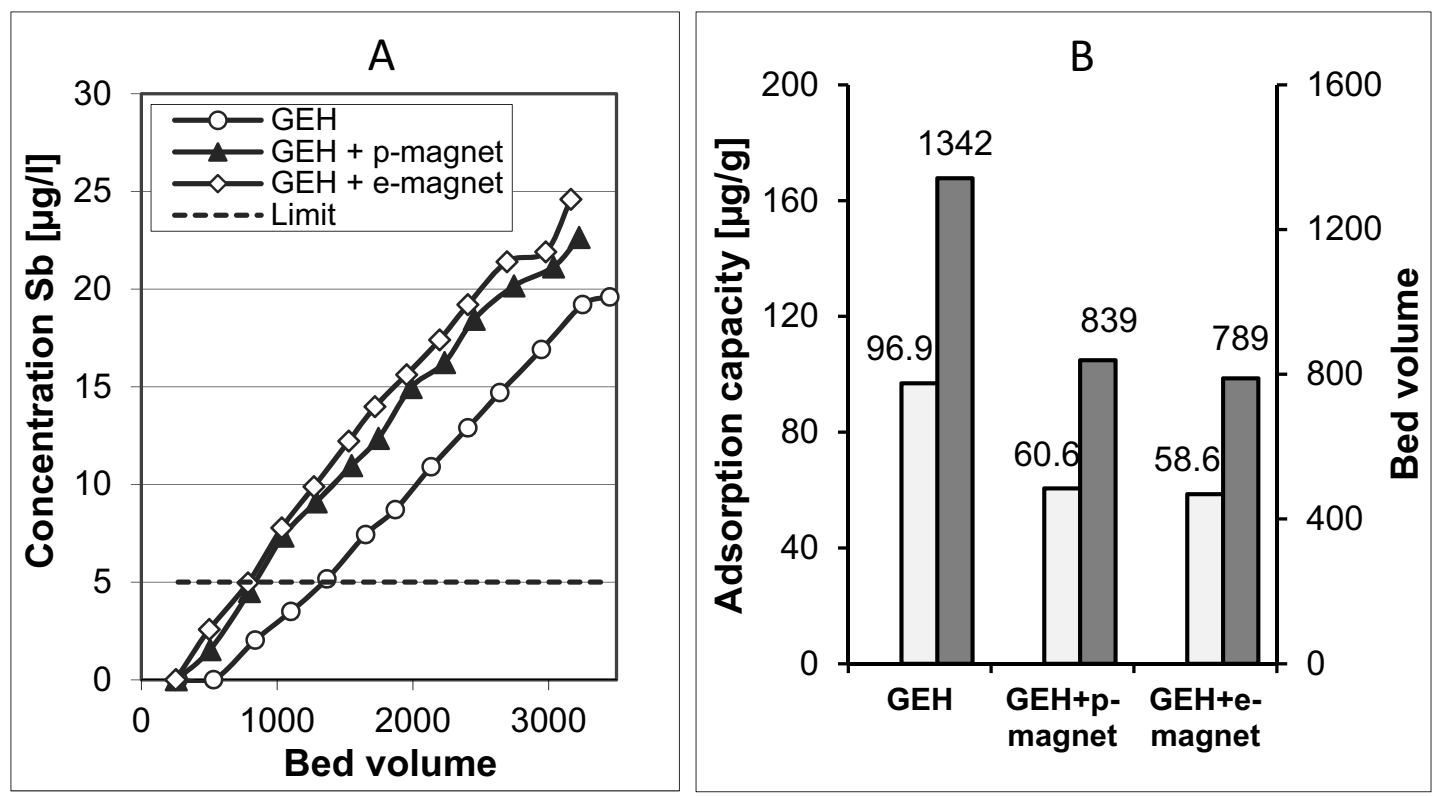

Fig. 9. Breakthrough curves of antimony (A) and bed volumes and adsorption capacity achieved (B) at breakthrough concentration of $5 \mu \mathrm{g} \mathrm{Sb} / \mathrm{L}$ (raw water concentration $81.4 \mu \mathrm{g} \mathrm{Sb} / \mathrm{L}$, filtration rate 5.4-5.6 $\mathrm{m} / \mathrm{h}$, EBCT 5.4-5.7 $\mathrm{min}$ ). 
medium increased from 610 to 1,550 (which would mean a 2.5 times longer adsorption cycle) was observed in additional experiments. WHO and public health authorities currently do not recommend using technologies based on the principle of applying a magnetic field to drinking water treatment. However, partially positive outcomes related to the effect of a magnetic field on the increase in GEH adsorption capacity in antimony removal indicate the need to continue with model tests technologically aimed at the specification of the factors influencing this process, at least to a certain extent.

\section{Acknowledgements}

Experimental measurements were carried out with the financial support of the APVV-0379-07 project from the Slovak Research and Development Agency and VEGA 1/0400/15 research project from the Scientific Grant Agency of the Slovak Ministry of Education, Science, Research and Sport. We would like to thank the employees of the Water Company of the Region of Liptov for their assistance.

\section{References}

1. PITTER P. Hydrochemie $4^{\text {th }}$ ed.; Institute of Chemical Technology Press, Prague, 2009 [In Czech].

2. WHO. Antimony in drinking-water. Background document for preparation of WHO Guidelines for drinking-water quality. Geneva, (WHO/SDE/WSH/03.04/74), 2003.

3. GRAY N.F. Drinking water quality - Problems and Solutions, $2^{\text {nd }}$ ed.; Cambridge University Press: New York, 2008.

4. US EPA: http://water.epa.gov/drink/contaminants/basicinformation/antimony.cfm, 2015.

5. US EPA. Drinking Water Standards and Health Advisories. EPA 820-R-11-002. Office of Water, Washington, DC, 2011.

6. WHO. Guidelines for Drinking-Water Quality. $4^{\text {th }}$ edition. WHO, Geneva. 2011.

7. Council Directive 98/83/EC, Quality of water intended for human consumption, 1998.

8. CRITTENDEN J.C., TRUSSELL R.R., HAND D.W., HOWE K.J., TCHOBANOGLOUS G. MWH's Water Treatment: Principles and Design, $3^{\text {rd }}$ ed.; Published by John Wiley \& Sons: Hoboken, New Jersey, 2012.

9. EDZWALD J.K. Water Quality and Treatment. A Handbook of Drinking Water, $6^{\text {th }}$ ed.; AWWA, McGraw-Hill Companies: New York, NY, 2011.

10. JAIN C.K., SINGH R.D. Technological options for the removal of arsenic with special reference to South East Asia. J. Environ. Manage. 107, 1, 2012.

11. MOHAN D., PITTMAN Ch.U. Jr. Arsenic removal from water/wastewater using adsorbents - A critical review. J. Hazard Mater. 142, (1-2), 1, 2007.

12. ILAVSKÝ J., BARLOKOVÁ D. The use of granular ironbased sorption materials for nickel removal from water. Pol. J. Environ. Stud. 21, (5), 1229, 2012.

13. GUO X., WU Z., HE M., MENG X., JIN X., QIU N., ZHANG J. Adsorption of antimony onto iron oxyhydroxides: Adsorption behavior and surface structure. J. Hazard Mater. 276, 339, 2014.
14. LIN T.F., LIU C.C., HSIEH W.H. Adsorption kinetics and equilibrium of arsenic onto an iron-based adsorbent and an ion exchange resin, Water Sci. Technol.: Water Supply 6, (2), 201, 2006.

15. DELIYANNI E.A., PELEKA E.N., MATIS K.A. Modeling the sorption of metal ions from aqueous solution by ironbased adsorbents. J. Hazard Mater. 172, 550, 2009.

16. GUAN X.H., WANG J., CHUSSUEI C.C. Removal of arsenic from water using granular ferric hydroxide: Macroscopic and microscopic studies. J. Hazard Mater. 156, 178, 2008.

17. GUAN X., DU J., MENG X., SUN Y., SUN B., HU Q. Application of titanium dioxide in arsenic removal from water: A review. J. Hazard Mater. 215-216, 1, 2012.

18. THIRUNAVUKKARASU O.S., VIRAGHAVAN T., SURAMANIAN K.S. Arsenic removal from drinking water using iron-oxide coated sand. Water Air Soil Poll. 142, 95, 2003.

19. MIAO Y., HAN F., PAN B., NIU Y., NIE G., LV L. Antimony $(\mathrm{V})$ removal from water by hydrated ferric oxides supported by calcite sand and polymeric anion exchanger. J. Environ. Sci. 26, (2), 307, 2014.

20. YU T., WANG X., LI C. Removal of Antimony by FeCl3Modified Granular-Activated Carbon in Aqueous Solution. J. Environ. Eng. 140, Special Issue: Drinking Water Safety, Security and Sustainability, A4014001, 2014.

21. ZHOU Z., DAI C., ZHOU X., ZHAO J., ZHANG Y. The Removal of Antimony by Novel NZVI-Zeolite: the Role of Iron Transformation. Water Air Soil Poll. 226, 76, 2015.

22. AREDES S., KLEIN B., PAWLIK M. The removal of arsenic from water using natural iron oxide minerals. J. Clean. Prod. 60, (1), 71, 2013.

23. ILAVSKÝ J., BARLOKOVÁ D., MUNKA K. Antimony Removal from Water by Adsorption to Iron-Based Sorption Materials. Water Air Soil Poll. 226, (1), Art. No: $2238,2015$.

24. NGUYEN V.L., CHEN W.H., YOUNG T., DARBY J. Effect of interferences on the breakthrough of arsenic: Rapid small scale column tests. Water Res. 45, 4069, 2011.

25. ZENG H., ARASHIRO M., GIAMMAR D.E. Effect of water chemistry and flow rate on arsenate removal by adsorption to an iron-based sorbent. Water Res. 42, 4629, 2008.

26. XI J., HE M., WANG K., ZHANG G. Adsorption of antimony(III) on goethite in the presence of competitive anions. J. Geochem. Explor. 132, 201, 2013.

27. MOSTAFA M.G., CHEN Y.H., JEAN J.S., LIU C.C., LEE J.C. Kinetics and mechanism of arsenate removal by nanosized iron oxide-coated perlite. J. Hazard Mater. 187, (1-3), 89, 2011.

28. DONG L., ZININ P.V., COWEN J.P., MING L.C. Iron coated pottery granules for arsenic removal from drinking water. J. Hazard Mater. 168, (2-3), 626, 2009.

29. JIA M., HU J.W., LUO J., DUAN S.M., LI Z.B., LIU C. Comparison Study on Adsorption and Removal of Antimony from Acidic Aqueous Solution by Activated Carbons and Machine-Made Charcoal. Advanced Materials Res. 779-780, 1600, 2013.

30. BASKAN M.B., PALA A. Removal of arsenic from drinking water using modified natural zeolite. Desalination 281, 396, 2011.

31. YANG X., SHI Z., LIU L. Adsorption of Sb(III) from aqueous solution by QFGO particles in batch and fixed-bed systems. Chem. Eng. J. 260, 444, 2015. 
32. CUMMING L.J., WANG L., CHEN A.S.C. Arsenic and Antimony Removal from Drinking Water by Adsorptive Media, U.S. EPA Demonstration Project at South Truckee Meadows General Improvement District (STMGID), NV Final Performance Evaluation Report, EPA/600/R-09/016, 2009.

33. MARIUSSEN E., JOHNSEN I.V., STRØMSENG A.E. Selective adsorption of lead, copper and antimony in runoff water from a small arms shooting range with a combination of charcoal and iron hydroxide. J. Environ. Manage. 150, 281, 2015.

34. MITSONOBU S., TAKAHASHI Y., TERADA Y., SAKATA M. Antimony(V) incorporation into synthetic ferrihydrite, geothite, and natural iron oxyhydroxides. Environ. Sci. Technol. 44, 3712, 2010.

35. SAZAKLI E., ZOUVELOU S.V., KALAVROUZIOTIS I., LEOTSINIDIS M. Arsenic and antimony removal from drinking water by adsorption on granular ferric oxide. Water Sci Technol. 71, (4), 622, 2015.

36. NAEEM A., WESTERHOFF P., MUSTAFA S. Vanadium removal by metal (hydr) oxide adsorbents. Water Res. 41, 1596, 2007.

37. Severn Trent Services: http://www.severntrentservices.com/ en_us/LiteratureDownloads/Documents/565_0200.pdf, 2015.

38. BACKMAN B., KETTUNEN V., RUSKEENIEMI T., LUOMA S., KARTTUNEN V. Arsenic removal from groundwater and surface water - Field tests in the Pirkanmaa Region, Finland. Geological Survey of Finland, Espoo, 1-40, 2007.

39. Kemwater ProChemie: http://www.prochemie.cz/chem/ tech-list-hydroxid-zelezity-kemira-cfh.pdf, 2015.

40. DRIEHAUS W., JEKEL M., HILDEBRANDT U. Granular Ferric Hydroxide - A New Adsorbent for the Removal of Arsenic from Natural Water. J. Water Supply Res. and Technol.-Aqua, 47, 30, 1998.

41. GEH Wasserchemie: http://www.geh-wasserchemie.de/ files/datenblatt_geh101_en_web.pdf, 2015.

42. WESTERHOFF P., BENN T., CHEN A., WANG L., CUMMING L. Assessing arsenic removal by metal (hydr)oxide adsorptive media using rapid small Scale Column Test. EPA/600/R-08/051, 2008.

43. BATHNAGAR A., CHOI Y., YOON Y., SHIN Y., JEON B.H., KANG J.W. Bromate removal from water by granular ferric hydroxide (GFH), J. Hazard Mater. 170, 134, 2009.

44. BADRUZZAMAN M., WESTERHOFF P., KNAPPE D.R. Intraparticle diffusion and adsorption of arsenate onto granular ferric hydroxide (GFH), Water Res. 38, (18), 4002, 2004.

45. SAHA B., BAINS R., GREENWOOD F. Physicochemical characterization of granular ferric hydroxide (GFH) for arsenic(V) sorption from water, Sep. Sci. Technol. 40, (14), 2909, 2005. 